Rush, S. A., C. Pekarik, D. V. Weseloh, F. Cuthbert, D. Moore, and L. Wires. 2015. Changes in heron and egret populations on the Laurentian Great Lakes and connecting channels, 1977-2009. Avian Conservation and Ecology 10(1): 7. https://doi.org/10.5751/ACE-00742-100107

Copyright (C) 2015 by the author(s). Published here under license by the Resilience Alliance.

Research Paper

\title{
Changes in heron and egret populations on the Laurentian Great Lakes and connecting channels, 1977-2009
}

\author{
Scott A. Rush ${ }^{1}$, Cynthia Pekarik ${ }^{2}$, D. V. Weseloh ${ }^{2}$, Francesca Cuthbert ${ }^{3}$, David Moore ${ }^{2}$ and Linda Wires ${ }^{3}$ \\ ${ }^{1}$ Mississippi State University, ${ }^{2}$ Canadian Wildlife Service, ${ }^{3}$ Department of Fisheries, Wildlife and Conservation Biology, University \\ of Minnesota
}

\begin{abstract}
Canadian and U.S. federal wildlife agencies completed four decadal surveys, spanning the years 1977 to 2009 , to census colonial waterbirds breeding on the Great Lakes and adjoining bodies of water. In this paper, we reports abundance, distribution, and general population trends of three species: Black-crowned Night-Heron (Nycticorax nycticorax), Great Egret (Ardea alba), and Great Blue Heron (Ardea herodias). Estimates of nest numbers ranged from approximately 4000-6100 for the Black-crowned Night-Heron, 250-1900 for the Great Egret, and 3800-6400 for the Great Blue Heron. Average annual rates of change in nest numbers between the first (1977) and fourth (2008) census were $-1 \%$ for the Black-crowned Night-Heron, $+23 \%$ for the Great Egret, and $-0.27 \%$ for the Great Blue Heron. Across the 30-year census, Black-crowned Night-Heron estimates decreased in U.S. $(-57 \%)$ but increased (+18\%) in Canadian waters, Great Egret nests increased $1381 \%$ in Canadian waters with a smaller, but still substantial increase in the number of nests at U.S. colonies (+613\%), and Great Blue Heron numbers increased $148 \%$ in Canadian waters and $713 \%$ in U.S. waters. Although a single factor cannot be clearly linked to changes observed in each species' distribution, hydrological variation, habitat succession, nest competition with Double-crested Cormorants (Phalacrocorax auritus), and land use changes likely all contributed. Management activities should support both breeding and foraging conditions including restoration of early successional habitats and anticipate continued northward expansions in the distributions of these waterbirds.
\end{abstract}

\section{Évolution des populations d'Ardéidés dans les Grands Lacs laurentiens et les milieux aquatiques adjacents, 1977-2009}

RÉSUMÉ. Les agences de la faune fédérales canadienne et étatsunienne ont complété quatre inventaires décennaux, de 1977 à 2009 , afin de suivre les populations d'oiseaux aquatiques coloniaux nichant dans les Grands Lacs et les milieux aquatiques adjacents. Nous dressons le portrait de l'abondance, de la répartition et des tendances générales des populations de trois espèces : le Bihoreau gris (Nycticorax nycticorax), la Grande Aigrette (Ardea alba) et le Grand Héron (Ardea herodias). Les estimations du nombre de nids se sont échelonnées de 4000 à 6100 environ pour le Bihoreau gris, de 250 à 1900 pour la Grande Aigrette et de 3800 à 6400 pour le Grand Héron. Le taux moyen de variation annuelle du nombre de nids entre le premier (1977) et le quatrième (2008) inventaire a été de $-1 \%$ pour le Bihoreau gris, de $+23 \%$ pour la Grande Aigrette et de $0,27 \%$ pour le Grand Héron. Durant les trente années du suivi, le nombre de Bihoreau gris a diminué aux États-Unis (-57\%) mais augmenté au Canada (+18\%), le nombre de nids de Grande Aigrette a subi une hausse dans les eaux canadiennes (+1 $381 \%)$ tout comme dans celles des États-Unis - hausse un peu moins prononcée mais quand même substantielle (+613\%) -, et le nombre de Grand Héron a grimpé de $148 \%$ du côté canadien et de $713 \%$ du côté étatsunien. Bien qu'il soit difficile d'identifier clairement un unique facteur responsable des changements survenus dans la répartition de chaque espèce, les variations hydrologiques, la succession végétale, la compétition pour les sites de nidification avec le Cormoran à aigrettes (Phalacrocorax auritus) et les changements dans l'utilisation des terres y ont vraisemblablement tous contribué. Nous croyons que les activités d'aménagement devraient cibler les conditions dans les aires de nidification et d'alimentation, dont la restauration de milieux en début de succession; de plus, les gestionnaires devraient anticiper la poursuite de la progression vers le nord de la répartition de ces espèces d'oiseaux aquatiques.

Key Words: Black-crowned Night-Heron; Great Blue Heron; Great Egret; habitat succession; islands; population trends

\section{INTRODUCTION}

Since the mid-1970s, the Canadian Wildlife Service (CWS) and the U.S. Fish and Wildlife Service (USFWS) have collaborated to census nesting colonial waterbirds on the Great Lakes at approximately 10-year intervals, reflecting four decadal surveys: the 1970s, 1980s, 1990s, and 2000s. Among the 15 species of colonial waterbirds that regularly breed on the Great Lakes, gulls, terns, cormorants, and pelicans have all been the subject of reasonably in-depth analyses of distributions and population trends over the duration of these efforts (e.g., Blokpoel 1977, Scharf and Shugart 1998, Weseloh et al. 2002, Morris et al. 2003, 2010, 2011, Pekarik et al. 2009). Species receiving minimal treatment to date are the herons and egrets (Blokpoel and Tessier 1998, Scharf and Shugart 1998).

One objective of the decadal surveys is to provide a complete assessment of the number of nesting pairs of the three main

Address of Correspondent: Scott A Rush, Dept Of Wildlife, Fisheries And Aquaculture, Box 9690, Mississippi State, MS, USA 39762, scott. rush@msstate.edu

Erratum: Appendix 3 in the original publication of this paper contained incorrect data. The correction was made on 17 September 2019. 
species of colonial tree-nesting herons and egrets that breed on the Great Lakes (Scharf and Shugart 1998): Black-crowned Night-Heron (Nycticorax nycticorax, hereafter, night-heron), Great Egret (Ardea alba, hereafter egret) and Great Blue Heron (Ardea herodias, hereafter heron). Population data for these three species, collected over more than 30 years, are useful for evaluating long-term changes in the distribution and abundance of each species, specifically population trends, species distributions, potential threats to breeding populations, and conservation assessments.

In this paper we present quantitative data on distribution and abundance, as well as assess general population trends, for these three species of colonial-nesting herons and egrets that breed on the Great Lakes and connecting channels. Drawing on recognized numerical and distributional changes, we provide possible explanations for differences observed among these species. We comment on management activities that can be implemented to help maintain the distributional diversity of these three species. Although each species discussed is migratory, we focus on potential limitations to the breeding season population of each species as it pertains to the Great Lakes region.

\section{Study area}

The North American Great Lakes system covers approximately $244,000 \mathrm{~km}^{2}$ and comprises the single largest body of fresh water in the world (Fuller et al. 2002). Lake Michigan is the only Great Lake that lies entirely within the United States. The other four Great Lakes are bisected by an international border that runs roughly down the middle of each lake and connecting channels.

For this study, we defined the Canadian Great Lakes as extending from the Canadian-U.S. border at the Pigeon River in western Lake Superior through lakes Superior, Huron, Erie, and Ontario, down the upper St. Lawrence River to the border between Ontario and Quebec, including the connecting channels of the St. Marys, St. Clair, Detroit, Niagara, and St. Lawrence rivers. The study area also extended $1 \mathrm{~km}$ inland along the shores of these water bodies. The U.S. Great Lakes study area included the U.S. shoreline of the Great Lakes and connecting rivers from Pigeon Point, Minnesota, at the Canada-U.S. border to Massena, New York, in the upper St. Lawrence River.

\section{METHODS}

Data collection protocols for the decadal Great Lakes Colonial Waterbird Censuses, 1977-2009, are detailed by Scharf et al. (1979), Blokpoel et al. (1980), Blokpoel and Tessier (1998), Weseloh et al. (1986, 2002), and Morris et al. (2003, 2010, 2011). Here we briefly describe them as they pertain to the census of night-herons, herons, and egrets with focus on four discrete periods: 1977-1980 (first census); 1989-1991 (second census); 1999-2001 (third census); and 2007-2009 (fourth census). Throughout we apply the term "colony" to represent a nesting area used by one or more pairs of individuals (Buckley and Buckley 1980, Blokpoel and Tessier 1998, Morris et al. 2003, 2010). We use the term "census" to identify a complete count of species and nests at colonies (Buckley and Buckley 1976, in Kushlan 1986), and the term "survey" as the effort to locate active colonies (see also Morris et al. 2003, 2011). During each census, nests were assigned to species on the basis of adults seen flushing from or flying in proximity to nests, identifiable eggs or chicks present in nests, or by qualities of the nest structure.

\section{Canadian data collection protocol}

In preparation for the first census (1977-1980), locations of known heron and egret colonies were obtained from local wildlife agencies, conservation authorities, museums, naturalist groups, and the public. During the third and fourth censuses, information from the Ontario breeding bird atlases was used to identify potential nesting colonies (Cadman et al. 2007). These surveys were conducted as part of a broader program to census colonial waterbirds on the Great Lakes. Therefore, most islands were also surveyed for gulls, terns, and cormorants; during those censuses, habitats on islands were surveyed for the presence of night-herons, herons, and egrets (Weseloh et al. 1986, 2002, Morris et al. 2003, 2010, 2011). In subsequent censuses, known colony sites were revisited; however, all islands, including those where no nesting was determined previously, were searched for the presence of new colonies.

Nearly all Canadian colonies of herons and egrets were located on islands and were visited by boat; a few colonies, accessible by automobile or foot, were located on the mainland. In the first census, heron nests in Lake Superior were counted from the air, from boats, and through on-the-ground surveys. For all other censuses, each nest tree was located and the number of nests of each species was recorded in colonies with relatively small numbers of nesting herons/egrets or in colonies located in small nesting areas or in habitat where all nest trees could be seen easily. On islands with larger numbers of nesting herons/egrets, or where the nesting area was extensive or all nests could not be seen easily, each nest tree was marked with flagging tape and the number of nests tallied. On very large islands, e.g., Middle, East Sister, and Middle Sister islands in western Lake Erie, transect lines were established across the entire island. Transect lines were walked abreast by $6-10$ observers until a census was made of the complete island. Each nest tree encountered during a transect census was marked to ensure that it was counted only once; we were highly confident that no nest trees were missed. In a few cases where ground vegetation was very dense, counts or estimates were made from a boat with estimates based on the number of nests observed extrapolated over the known area of the colony. Although all Canadian censuses were coordinated by CWS staff in Ottawa and Burlington, partners from the Ontario Ministry of Natural Resources, Parks Canada, various Conservation Authorities, and universities who participated were trained in using CWS methods.

\section{U.S. data collection protocol}

Although the protocol for the first U.S. censuses was developed independent of Canada, the U.S. censuses were still very similar to the Canadian ones, with the exception that aerial techniques were used more extensively for U.S. censuses. In the first U.S. census, the shorelines and islands in the study area were flown with a Cessna 180 on floats, and an investigator counted the number of nesting pairs in small colonies from the air. At larger colonies, the plane landed near the site and 1-2 persons went ashore and conducted the census, either a full census or a partial census with extrapolation (Scharf et al. 1979). In the second and subsequent U.S. censuses, the aerial census was complimented by several teams of boat-based surveyors (Scharf and Shugart 1998, Morris et al. 2003) using techniques similar to those used in Canadian censuses. The only exception was on West Sister Island in western Lake Erie, where study plots were established and the number of nesting pairs per plot was extrapolated to the entire 
Table 1. Location, size, and number of active Black-crowned Night-Heron (Nycticorax nycticorax) colonies by country and water body during the four decadal census periods. Values reflect total nest count per water body with number of active colony sites shown in parentheses. Water bodies are presented on an east-west gradient. Values of zero indicate no nesting activity reported in water body during the indicated census period. NA denotes "not applicable" because the water body does not occur in both jurisdictions. DR indicates Detroit River; LE, Lake Erie; LH, Lake Huron; LM, Lake Michigan; LO, Lake Ontario; LSC, Lake St. Clair; LS, Lake Superior; NR, Niagara River; SLR, St. Lawrence River; SMR, St. Marys River.

\begin{tabular}{|c|c|c|c|c|c|c|c|c|c|c|c|c|c|}
\hline $\begin{array}{r}\text { Census } \\
\text { Year }\end{array}$ & SLR & $\mathrm{LO}$ & NR & $\mathrm{LE}$ & DR & LSC & $\begin{array}{r}\text { LH } \\
\text { Main } \\
\text { body } \\
\end{array}$ & $\begin{array}{r}\text { LH } \\
\text { Georgian } \\
\text { Bay } \\
\end{array}$ & $\begin{array}{r}\text { LH } \\
\text { North } \\
\text { Channel } \\
\end{array}$ & LM & SMR & LS & $\begin{array}{r}\text { Total nest } \\
\text { (Sites) }\end{array}$ \\
\hline \multicolumn{14}{|c|}{ Canadian Sites } \\
\hline 1977 & 0 & $232(5)$ & $65(1)$ & $1220(2)$ & 0 & 0 & $154(3)$ & $175(3)$ & 0 & $N A$ & 0 & 0 & $1846(14)$ \\
\hline 1991 & 0 & $996(10)$ & $426(3)$ & $151(2)$ & 0 & $98(2)$ & $152(4)$ & $110(2)$ & 0 & $N A$ & 0 & 0 & $1933(23)$ \\
\hline 1999 & $46(1)$ & $1466(6)$ & $246(2)$ & 98 (4) & 0 & 0 & $206(8)$ & $242(9)$ & $9(4)$ & $N A$ & 0 & 0 & $2313(34)$ \\
\hline 2008 & $142(8)$ & $839(10)$ & $378(3)$ & $65(4)$ & $57(1)$ & 0 & $205(11)$ & 448 (12) & $49(8)$ & $N A$ & 0 & 0 & $2183(57)$ \\
\hline \multicolumn{14}{|c|}{ U.S. Sites } \\
\hline 1977 & --- & $130(1)$ & 0 & $3000(1)$ & 0 & 0 & $230(7)$ & $N A$ & $N A$ & $860(13)$ & 0 & 0 & $4220(22)$ \\
\hline 1991 & 0 & $12(1)$ & 0 & $1568(3)$ & 0 & 0 & $361(7)$ & $N A$ & $N A$ & $859(10)$ & 0 & 0 & $2800(21)$ \\
\hline 1999 & 0 & $54(4)$ & $38(1)$ & $460(2)$ & 0 & 0 & $561(7)$ & $N A$ & $N A$ & $527(14)$ & 0 & 0 & $1640(28)$ \\
\hline 2008 & 0 & $94(2)$ & $98(1)$ & 767 (4) & 0 & 0 & $287(8)$ & $N A$ & $N A$ & $578(20)$ & $6(1)$ & $3(1)$ & $1833(37)$ \\
\hline \multicolumn{14}{|l|}{ Combined } \\
\hline 1977 & & $362(6)$ & $65(1)$ & $4220(3)$ & 0 & 0 & $384(10)$ & $175(3)$ & 0 & $860(13)$ & 0 & 0 & $6066(36)$ \\
\hline 1991 & & $1008(11)$ & $426(3)$ & $1719(5)$ & 0 & $98(2)$ & $513(11)$ & $110(2)$ & 0 & $859(10)$ & 0 & 0 & $4733(44)$ \\
\hline 1999 & $46(1)$ & $1520(10)$ & $284(3)$ & $558(6)$ & 0 & 0 & $767(15)$ & $242(9)$ & $9(4)$ & $527(14)$ & 0 & 0 & $3953(62)$ \\
\hline 2008 & $142(8)$ & $933(12)$ & $476(4)$ & $832(8)$ & $57(1)$ & 0 & 492 (19) & 448 (12) & $49(8)$ & $578(20)$ & $6(1)$ & $3(1)$ & $4016(94)$ \\
\hline
\end{tabular}

site (Shieldcastle and Martin 1997). In the fourth census, estimates of nesting pairs were obtained during ground counts and by counting nests from aerial photographs (described in Cuthbert and Wires 2013). All cooperators were provided with written protocols for censusing each species (Cuthbert and Wires 2013).

In the first census, the U.S. portion of the St. Lawrence River was not included in the study area. However, it was included in the three subsequent censuses.

\section{Nest identification}

During all censuses, only Apparently Occupied Nests (Ewins et al. 1995) were recorded. These were nests that were either empty but freshly built and/or appeared to be actively maintained, or nests that contained eggs and/or chicks. Nests usually were identified by the presence of an adult, presumed to be the nest owner, or the presence of eggs or chicks at the nest. Night-heron nests were identified by their small, compact size, use of small twigs in nest construction, and usually low placement of the nest in the canopy. Egret nests were smaller than heron nests, not as densely constructed, and usually lower in the canopy than heron nests. Heron nests were identified by their large bulky size and solid appearance, usually at the tops of trees.

\section{Rates of numerical change}

Estimates of average colony size were developed using only those colonies active during a census. Because of the missing data from the U.S. portion of the St. Lawrence River in the first census, nest count data were derived from Maxwell et al. (2000), facilitating estimates of rate of change within this water body across surveys. Statistical comparisons of nest numbers among censuses included all colonies. Countrywide and Great Lakes-wide variation in the total number of nests among censuses was analyzed for each species with generalized linear mixed effect models, which used maximum likelihood via the lmer function in the lme4 package of
R 2.12.1 (R Development Core Team 2012). Each model contained nest count as the response variable and census as the fixed effect, which was treated as a continuous variable. Separate analyses were used to estimate population trends across each water body (defined in Table 1) and separately within each country. When estimating regional trends, water body was treated as a random effect with country nested within water body. Canadian and U.S. trends were estimated with water body alone treated as the random effect. All models were fit using a Poisson error distribution and log-link function.

A separate analysis was used to evaluate lakewide regional changes in nest numbers among census years. This analysis used a model structure similar to that used in evaluating national differences, except census was treated as a categorical variable. Differences among main effects (census) were analyzed using the general linear hypothesis testing ( $g l h t$ ) function of the multcomp package in R (R Development Core Team 2012). This function allows for testing among specified contrasts, which in our case compared the response variables among adjacent censuses.

\section{RESULTS}

\section{Great Lakes-wide distribution, nest estimates, and trends}

For each species, the number of nests (equivalent to nesting pairs) and colony sites (see Fig. 1 for distribution) recorded in each census are shown separately by country and as combined totals (Tables 1-3). The average annual rates of change in nest numbers between the first (1977) and fourth (2008) census were $-1 \%$ for night-heron, $+23 \%$ for egret, and $-0.27 \%$ for heron. Trends for individual species indicated the number of nesting night-herons decreased, egrets increased, and herons remained relatively stable across the 30-year study. 
Fig. 1. The distribution of Black-crowned Night-Heron, Great Egret, and Great Blue Heron colonies found during four decadal surveys. (A) Locations of all 78 colonies located in 1976-2009. (B) Locations of colonies showing the greatest change in numbers, 1977-2008.
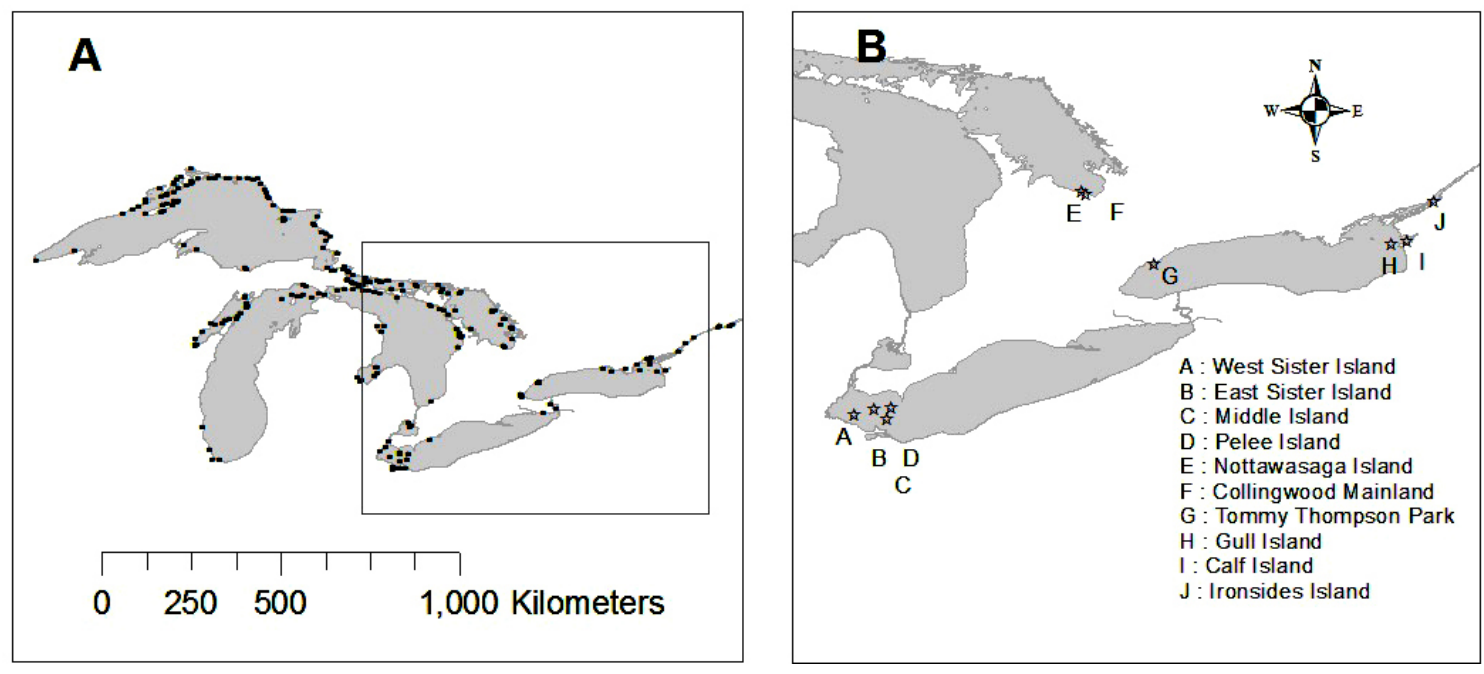

\section{Black-crowned night-herons}

During the first two censuses in 1977 and 1991, the greatest number of night-heron nests within the Great Lakes occurred in Lake Erie. The greatest nest numbers occurred in Lake Ontario during the third census in 1999 and in Lake Huron in the fourth census in 2008 (Table 1). Throughout the 30-year census, across the Great Lakes, the average colony size for night-herons was 80 \pm 245 nests ( $n=142$ colonies). The average night-heron colony size decreased $75 \%$ over this time (Appendices 1 and 2, pooled). Great Lakes-wide reductions in nest numbers were evident between each of the first three censuses (all $\mathrm{P}<0.05$ ), with the greatest annual decline during the eight-year period between 1977 and 1991 ( $1.6 \%$ per year; $Z=-7.21$, df $=1, P<0.001$; Table 1$)$. However, between 1999 and 2008, this species experienced a small (1.6\%) but not statistically significant $(\mathrm{Z}=0.70, \mathrm{df}=1, \mathrm{P}=0.82)$ increase in Great Lakes-wide nest numbers (Table 1). The combined nest numbers in the last census decreased by $34 \%$ from those in the first census (Table 1).

In Canadian waters of the Great Lakes, the average night-heron colony during the 30 -year census was $65 \pm 157$ nests $(n=84$ colonies; Appendix 1). On average, colony size decreased $71 \%$ during this time. The greatest between-census change in nightheron nest numbers occurred between 1991 and 1999: a 20\% increase (Table 1). However, because of an increase in the number of colonies from 23 to 34 during this time, the mean number of nests per colony decreased by $19 \%(Z=-7.87$, df $=1, P<0.001)$. There was no significant change in population size or average colony size between 1999 and $2008(\mathrm{Z}=0.63$, $\mathrm{df}=1, \mathrm{P}=0.866)$. In 1977, Lake Erie had the greatest number of nests, with the single highest nest numbers occurring on Pelee Island $(n=870$ nests; Appendix 1). This site was abandoned completely by nightherons by the second survey in 1991 (Appendix 1). By 1991 the number of nests in Lake Ontario exceeded the number in Lake Erie, with the highest nest counts recorded at Tommy Thompson Park, Toronto Harbor ( $\mathrm{n}=567$ nests; Appendix 1).
In U.S. waters, during the entire census, mean night-heron colony size was $97 \pm 319$ nests $(n=58$; Appendix 2), but did not differ significantly from the size in Canadian waters $(Z=0.75$, $\mathrm{df}=1$, $\mathrm{P}=0.46$; Appendix 2). In the United States, over the 30-year census, numbers of night-heron nests declined significantly, with an estimated $57 \%$ loss across all four censuses (Table 1). This decline was evidenced by a $34 \%$ reduction in nest numbers between 1977 and $1991(\mathrm{Z}=-16.83$, df $=1, \mathrm{P}<0.001)$ and 41\% between 1991 and 1999 ( $Z=-17.2$, df $=1, P<0.001$; Appendix 1). Despite this downward trend prior to 1999 , nest numbers increased $12 \%$ between 1999 and $2008(Z=3.27, d f=1, P=0.003$; Table 1).

The general decrease in estimates for this species among early censuses was most evident between the first (1977) and third (1991) census in Lake Erie, where the population declined $85 \%$ in U.S. sites and $92 \%$ in Canadian sites (Table 1). In the first census in 1977, a single site in Lake Erie (West Sister Island, Canada; Fig. 1) contained $71 \%$ of all nests within that water body $(n=$ 3000 nests; Appendix 2). By 2008 the number of nests at this location had declined $85 \%$ to 460 nests (Appendix 2). Concomitant with the observed declines in the U.S. and Canadian open lake waters, at riverine locations nesting populations of night-herons increased nearly 10 -fold over the four censuses, spanning 1977 to 2008, in the St. Marys, Detroit, Niagara, and St. Lawrence Rivers (Table 1).

\section{Great egrets}

During the first census in 1977, only 245 egret nests were found in the entire Great Lakes and all were in Lake Erie, the Detroit River, and Lake St. Clair. By the fourth census, nesting egrets had expanded to all the Great Lakes, including more than 800 nests in Lakes Huron and Michigan (Table 2). The Great Lakes-wide number of nests increased $571 \%$ from 1977 to 1991 ( $Z=27.79$, df $=1, \mathrm{P}<0.001)$, decreased $17 \%$ from 1991 to $1999(Z=-4.99$, df $=1, \mathrm{P}<0.001)$, and increased $39 \%$ between 1999 and $2008(\mathrm{Z}$ $=9.34, \mathrm{df}=1, \mathrm{P}<0.001$; Table 2). Overall, the number of nests 
Table 2. Location, size, and number of active Great Egret (Ardea alba) colonies by country and water body during the four decadal census periods. Values reflect total nest count per water body with number of active colony sites shown in parentheses. Water bodies are presented on an east-west gradient. Values of zero indicate no nesting activity reported in water body during the indicated census period. NA denotes "not applicable" because the water body does not occur in both jurisdictions. DR indicates Detroit River; LE, Lake Erie; LH, Lake Huron; LM, Lake Michigan; LO, Lake Ontario; LSC, Lake St. Clair; LS, Lake Superior; NR, Niagara River; SLR, St. Lawrence River; SMR, St. Marys River.

\begin{tabular}{|c|c|c|c|c|c|c|c|c|c|}
\hline Census Year & LO & NR & LE & $\mathrm{DR}$ & LSC & $\begin{array}{r}\mathrm{LH} \\
\text { main body }\end{array}$ & $\begin{array}{r}\text { LH } \\
\text { Georgian } \\
\text { Bay } \\
\end{array}$ & LM & $\begin{array}{r}\text { Total nest } \\
\text { (Sites) }\end{array}$ \\
\hline \multicolumn{10}{|l|}{ Canadian Sites } \\
\hline 1977 & 0 & 0 & $21(3)$ & 0 & 0 & 0 & 0 & $N A$ & $21(3)$ \\
\hline 1991 & 0 & 0 & $143(2)$ & 0 & 0 & $6(1)$ & $7(1)$ & $N A$ & $156(4)$ \\
\hline 1999 & $2(1)$ & 0 & $32(2)$ & 0 & 0 & $20(1)$ & $40(1)$ & $N A$ & $94(5)$ \\
\hline 2008 & $33(2)$ & 0 & $61(3)$ & 0 & 0 & $76(3)$ & $141(1)$ & $N A$ & $311(9)$ \\
\hline \multicolumn{10}{|l|}{ U.S. Sites } \\
\hline 1977 & 0 & 0 & $200(1)$ & $23(1)$ & $1(1)$ & 0 & $N A$ & 0 & $224(3)$ \\
\hline 1991 & 0 & 0 & 1425 (4) & 0 & 0 & $62(2)$ & $N A$ & 0 & 1487 (6) \\
\hline 1999 & 0 & 0 & $884(3)$ & 0 & 0 & 377 (2) & $N A$ & $7(1)$ & $1275(7)$ \\
\hline 2008 & 0 & $20(1)$ & $948(4)$ & 0 & 0 & $443(5)$ & $N A$ & $187(5)$ & $1598(15)$ \\
\hline \multicolumn{10}{|l|}{ Combined } \\
\hline 1977 & 0 & 0 & $221(4)$ & $23(1)$ & $1(1)$ & 0 & 0 & 0 & $245(6)$ \\
\hline 1991 & 0 & 0 & $1568(6)$ & 0 & 0 & $68(3)$ & $7(1)$ & 0 & $1643(10)$ \\
\hline 1999 & $2(1)$ & 0 & $916(5)$ & 0 & 0 & $397(3)$ & $40(1)$ & $7(1)$ & 1369 (12) \\
\hline 2008 & $33(2)$ & $20(1)$ & $1009(7)$ & 0 & 0 & $519(8)$ & $141(1)$ & $187(5)$ & $1909(24)$ \\
\hline
\end{tabular}

of egrets across the Great Lakes increased by $679 \%$ between the first (1977) and fourth (2008) census, a change dominated by the nesting colonies on Lakes Erie and Huron (Table 2).

In Canadian waters, during the 30 -year census, the average colony size for egrets was $28 \pm 43$ nests $(n=13$ colonies; Appendix 3$)$. The number of egret nests at Canadian colonies increased $1381 \%$ across the 30-year census (Table 2). However, the positive trend in egret nest numbers was not consistent among surveys; egret numbers at Canadian locations increased $643 \%$ from 1977 to 1991 ( $\mathrm{Z}=9.75$, df $=1, \mathrm{P}<0.001$ ), decreased $40 \%$ between 1991 and $1999(\mathrm{Z}=-3.88$, df $=1, \mathrm{P}<0.001)$, and increased $231 \%$ between 1999 and 2008 ( $Z=8.63$, df $=1, P<0.001)$, (Table 2).

During the entire 30 -year census, nesting by egrets fluctuated at colonies in Lake Erie but steadily increased in Lake Huron (Table 2). In 1977, the largest Canadian colony was on East Sister Island in Lake Erie (Fig. 1). Consisting of 10 nests in 1977, this colony increased through 1991 to 141 nests, decreased to 17 nests by 1999 , and decreased to 12 nests in 2008 (Appendix 3). With this decline in Lake Erie, nesting shifted to Lake Huron, with the largest colony in 1999 located on Nottawasaga Island (40 nests; Fig. 1). The colony at Nottawasaga Island continued to increase and remained the largest colony through 2008 (141 nests; Appendix 3).

In U.S. waters, egret colonies averaged $148 \pm 261$ nests $(n=21$ colonies; Appendix 4). Because of the huge range in colony size, governed by the large size of the colony on West Sister Island (Appendix 4), U.S. colonies were not significantly different in size from Canadian colonies $(Z=0.81$, df $=1, P=0.42)$. Across the 30 -year census the number of egrets nesting in U.S. waters increased $613 \%$ (Table 2). Among the U.S. colonies, egret nest numbers followed trends similar to those in Canadian waters, with a 564\% increase between 1977 and $1991(\mathrm{Z}=26.41$, df $=1, \mathrm{P}<$
0.001), a 14\% decrease between 1991 and $1999(\mathrm{Z}=-4.03$, df $=$ $1, \mathrm{P}<0.001)$, and a 25\% increase between 1999 and $2008(\mathrm{Z}=$ $6.01, \mathrm{df}=1, \mathrm{P}<0.001)$. The decrease in U.S. colony size between 1991 and 1999 was less than that observed at Canadian sites ( $-14 \%$ at U.S. sites compared with $-40 \%$ at Canadian sites; Table 2) during the same period.

Throughout the census, the largest egret colony in U.S. waters was located on West Sister Island in Lake Erie (Fig. 1). The number of nests at this location increased from 200 nests in 1977 to 1040 nests in 1991. In 1999, the number of nests in this colony decreased to 840 nests, with a subsequent decrease to 760 nests in 2008 . The decline in nest numbers in Lake Erie colonies after 1991 tracked a northward shift toward colonies in Lake Huron, including a $407 \%$ increase in the number of nests within Lake Huron's Georgian Bay (Table 1 and Appendix 4). Egrets were first noted nesting at locations in Lake Michigan during the third census in 1999 and increased more than 26-fold in that water body by 2008 (Table 2).

\section{Great blue herons}

Between 1977 and 1991, the number of heron nests increased 43\% throughout the Great Lakes $(\mathrm{Z}=21.14$, df $=1, \mathrm{P}<0.001)$. The Great Lakes-wide population then decreased $26 \%$ from 1991 to 1999 ( $Z=-15.94$, df $=1, P<0.001)$, with an additional $18 \%$ decline from 1999 to $2008(Z=-9.13$, df $=1, P<0.001$; Table 3$)$. Great Lakes-wide changes during the 30 -year census reflect a $14 \%$ decline (Table 3). The greatest numbers of heron nests were consistently counted at locations in Lake Erie (Table 3).

In Canadian waters, across all four censuses, the average heron colony was $19 \pm 34$ nests $(n=116$ colonies; Appendix 5). Between 1977 and 1991, the average size of a Canadian colony increased $19 \%(Z=3.97, \mathrm{df}=1, \mathrm{P}<0.001)$, decreased $44 \%$ between 1991 and $1999(Z=-11.59$, df $=1, P<0.001)$, and then increased $38 \%$ 
Table 3. Location, size, and number of active Great Blue Heron (Ardea herodias) colonies by country and water body during the four decadal census periods. Values reflect total nest count per water body with number of active colony sites shown in parentheses. Values of zero indicate no nesting activity reported in water body during the indicated census period. NA denotes "not applicable" because the water body does not occur in both jurisdictions. DR indicates Detroit River; LE, Lake Erie; LH, Lake Huron; LM, Lake Michigan; LO, Lake Ontario; LSC, Lake St. Clair; LS, Lake Superior; NR, Niagara River; SLR, St. Lawrence River; SMR, St. Marys River.

\begin{tabular}{|c|c|c|c|c|c|c|c|c|c|c|c|c|c|}
\hline $\begin{array}{l}\text { Census } \\
\text { Year }\end{array}$ & SLR & $\mathrm{LO}$ & NR & $\mathrm{LE}$ & DR & LSC & $\begin{array}{c}\text { LH } \\
\text { Main } \\
\text { body }\end{array}$ & $\begin{array}{c}\text { LH } \\
\text { Georgian } \\
\text { Bay }\end{array}$ & $\begin{array}{c}\text { LH } \\
\text { North } \\
\text { Channel }\end{array}$ & $\mathrm{LM}$ & SMR & $\mathrm{LS}$ & $\begin{array}{r}\text { Total nest } \\
\text { (Sites) }\end{array}$ \\
\hline \multicolumn{14}{|c|}{ Canadian Sites } \\
\hline 1977 & 0 & 0 & 0 & $76(2)$ & 0 & 0 & $73(8)$ & $275(5)$ & $206(9)$ & $N A$ & 0 & $328(35)$ & 958 (59) \\
\hline 1991 & $125(1)$ & $20(2)$ & 0 & $368(3)$ & 0 & 0 & $188(2)$ & $147(2)$ & $82(5)$ & $N A$ & $3(1)$ & 207 (27) & $1140(43)$ \\
\hline 1999 & 0 & $5(1)$ & 0 & $69(3)$ & 0 & 0 & $63(7)$ & $158(6)$ & $108(7)$ & $N A$ & 0 & 241 (24) & $644(48)$ \\
\hline 2008 & $74(2)$ & $26(1)$ & 0 & $326(3)$ & 0 & 0 & $94(9)$ & $116(8)$ & $43(6)$ & $N A$ & $1(1)$ & 207 (13) & $887(43)$ \\
\hline \multicolumn{14}{|c|}{ U.S. Sites } \\
\hline 1977 & $279(1)^{\dagger}$ & 0 & 0 & $2538(2)$ & $11(1)$ & $37(1)$ & $187(7)$ & $N A$ & $N A$ & $149(9)$ & 99 (3) & $199(5)$ & 3499 (29) \\
\hline 1991 & 1001 (1) & 0 & 0 & $2546(5)$ & 0 & 0 & $464(7)$ & $N A$ & $N A$ & 459 (14) & 277 (7) & $478(20)$ & $5225(54)$ \\
\hline 1999 & $793(1)$ & 0 & $40(1)$ & $2122(4)$ & 0 & 0 & 347 (10) & $N A$ & $N A$ & $324(9)$ & $188(9)$ & $225(14)$ & 4039 (48) \\
\hline 2008 & $35(2)$ & 0 & $61(1)$ & $2078(6)$ & $194(1)$ & 0 & $131(5)$ & $N A$ & $N A$ & $204(8)$ & $113(8)$ & $136(4)$ & $2952(35)$ \\
\hline \multicolumn{14}{|c|}{ Combine } \\
\hline 1977 & $279(1)$ & 0 & 0 & $2614(4)$ & $11(1)$ & $37(1)$ & $260(15)$ & $275(5)$ & $206(9)$ & $149(9)$ & $99(3)$ & $527(38)$ & $4457(88)$ \\
\hline 1991 & $1126(2)$ & $20(2)$ & 0 & $2914(8)$ & 0 & 0 & $652(9)$ & $147(2)$ & $82(5)$ & 459 (14) & $280(8)$ & $685(47)$ & 6365 (97) \\
\hline 1999 & $793(1)$ & $5(1)$ & $40(1)$ & $2191(7)$ & 0 & 0 & 410 (17) & $158(6)$ & $108(7)$ & $324(9)$ & $188(9)$ & $466(38)$ & 4683 (96) \\
\hline 2008 & $109(4)$ & $26(1)$ & $61(1)$ & $2404(9)$ & $194(1)$ & 0 & $225(14)$ & $116(8)$ & $43(6)$ & $204(8)$ & $114(9)$ & $343(17)$ & $3839(78)$ \\
\hline
\end{tabular}

${ }^{\dagger}$ Data obtained from Maxwell et al. 2000

between 1999 and $2008(Z=6.18, d f=1, P<0.001)$. The largest colonies of herons in Canadian waters shifted between lakes Erie and Huron during the 30-year census. During 1977, the greatest number of nests $(n=97)$ was found at the Collingwood Mainland site in Lake Huron (Fig. 1, Appendix 5). In 1991, the largest number of nests was recorded at East Sister Island in Lake Erie (248 nests; Fig. 1, Appendix 5). By 1999, the East Sister Island colony had decreased $95 \%$ to 12 nests, with the largest colony (67 nests) then found on Nottawasaga Island in Lake Huron (Fig. 1, Appendix 5). During 2008, the Nottawasaga Island colony contained 20 nests (reflecting a 70\% decrease since 1991), with the largest colony (304 nests) located on Middle Island in Lake Erie (Fig. 1).

In U.S. waters, average heron colony size was $94 \pm 249$ nests $(\mathrm{n}=$ 79 colonies), larger than Canadian counterparts $(Z=63.89, \mathrm{df}=$ 1, P $<0.001$; Table 3, Appendix 6). Numbers of heron nests in $\mathrm{U}$. S. waters increased 49\% between 1977 and $1991(\mathrm{Z}=18.36$, $\mathrm{df}=$ $1, \mathrm{P}<0.001$; Appendix 6) and decreased significantly by $23 \%$ between 1991 and 1999 censuses $(Z=-12.29$, df $=1, P<0.001)$ and by $27 \%$ between the 1999 and 2008 censuses $(Z=-12.95$, df $=1, \mathrm{P}<0.001 ;$ Appendix 6).

Among U.S. colonies, the number of heron nests was consistently highest on West Sister Island in Lake Erie, yet the number of nests in this colony declined through this 30-year study (Fig. 1, Appendix 6). The second-largest colony, on Ironsides Island in the St. Lawrence River (Fig. 1), was established sometime after 1977, when no herons were found nesting at this location, and before 1991, when this colony consisted of 1001 nests. In the years following, the colony on Ironsides Island decreased to 793 nests (Maxwell et al. 2000). In 2008, no herons were found nesting at this location (L. Harper, unpublished data).

\section{DISCUSSION}

In this study, from the first to the fourth censuses, we found that number of nests of night-herons declined 34\%, egrets increased $679 \%$, and herons declined $14 \%$. The largest decreases in nest numbers of night-herons and herons occurred in U.S. Lake Erie. Over the same time period, we also found that the number of breeding colonies for night-herons increased $161 \%$, egrets increased $300 \%$, and herons declined by $11 \%$. The greatest loss in the number of breeding colonies of herons occurred in Canadian Lake Superior. Despite divergent population trends between night-herons and egrets, both species exhibited northward range expansions, most evident in Lake Huron's Georgian Bay.

Of the few losses documented in this study, the decline in the number of nests of night-herons is perhaps the most serious. Within the Great Lakes region, the night-heron is considered a species of moderate conservation concern, whereas the egret and heron are considered species not at risk (Wires et al. 2010). There was a net loss of more than 2000 night-heron nests during this study. Virtually all of them can be accounted for by the nearly 3800 nests that were lost from Pelee, East Sister, and West Sister Islands on the Canadian and U.S. sides of Lake Erie and the gain of just over 1800 nests in the St. Lawrence River, Lake Ontario, the Niagara River, and Lake Huron. Although this identifies where the loss appears to have occurred, it does not explain why it occurred. What could have caused the loss of so many nightheron nests from western Lake Erie?

More than 800 night-heron nests were lost from Pelee Island very soon after 1977. This may have resulted from human disturbance (Tremblay and Ellison 1979, Hockin et al. 1992, Rodgers and Smith 1995, Carney and Syndeman 1999). Pelee Island is accessible from the Canadian and U.S. mainlands by regular ferry service during spring, summer, and autumn, and is a popular bird- 
watching location. The nesting area, at the south end of the island, was accessible by foot traffic and entry was not prohibited. These birds may have moved to Middle Island, $3 \mathrm{~km}$ away, because more than 400 night-heron nests were counted there in 1981, and more than 900 in 1983 (Weseloh et al. 1988).

Since the first census, land-use and hydrologic changes have occurred across the Great Lakes basin, potentially influencing the distribution of waterbird colonies (Smith et al. 1991, Herdendorf 1992, Frieswyk and Zedler 2007). Small-scale changes in waterbird colonies can be linked to the direct alteration of supporting habitat. For example, anthropogenic development of the Collingwood Mainland heron colony site rendered this site no longer available to herons (D. V. Weseloh, personal observation). Loss of the heron colony on Ironsides Island also paralleled the loss of nest habitat and possible disturbance by raccoons (Procyon lotor; Maxwell et al. 2000; L. Harper, unpublished data). In 1991, 1001 heron nests were recorded at this site. As the trees that supported these nests slowly died, nests on the island decreased $21 \%$ to 793 in 1999 . By the census of 2008 , no herons were recorded nesting at this location. On West Sister Island, in the Ohio waters of Lake Erie, the loss of some nightheron nests has been attributed to vegetative successional changes, i.e., habitat loss, as the forest on that island matured. The preferred nesting habitat of night-herons, i.e., low canopy and shrubby vegetation, gave way to taller, older trees (Shieldcastle and Martin 1997).

The third, and perhaps most significant, potential factor is the population growth of cormorants and their usurpation of nightheron nests on Middle, East Sister, Middle Sister, and West Sister islands in western Lake Erie during this study. From 1979 to 2008, the number of cormorant nests on these islands increased from 78 to 13,846 (Weseloh et al. 2002, Wires and Cuthbert 2006; D. $\mathrm{V}$. Weseloh, unpublished data). It is well known that cormorants can defoliate, influence vegetative structure and diversity, and eventually kill the trees and shrubs in which they nest (Lemmon et al. 1994, Weseloh et al. 2002, Hebert et al. 2005, Boutin et al. 2011), greatly reducing available habitat for conesting species such as night-herons, egrets, and herons. It is also well known that when cormorants initially colonize an island, they often aggressively attempt to take over nests of tree-nesting heron/egret species (Dorr et al. 2014). Being the smallest of the three heron species in this study, night-herons probably suffered most to the much larger and aggressive cormorant.

The potential impact of species interactions on bird colonies has received some previous study. Competitive and/or predatory interactions among some colonially nesting species can facilitate changes in reproductive success that can affect population growth and size (Burger 1981, Skagen et al. 2001). Cuthbert et al. (2002) found that increased cormorant populations alone were not directly tied to changes in waterbird abundance throughout the Great Lakes basin. Changes in heron/egret nest numbers as reflected herein tend to support that finding. However, on an individual island basis in Lake Ontario, we noted that the abrupt abandonment of 7 of $20(35 \%)$ night-heron colonies was anecdotally associated with the arrival or increase in the number of nesting cormorants (Appendix 1; Weseloh et al. 2002; D. V. Weseloh, unpublished data). It was also noted that as cormorants moved into various already established night-heron colonies, the night-herons abandoned the colony site if no other suitable habitat was immediately available. If other habitat was available, the night-herons often moved to that habitat and did not abandon the overall/general breeding island/site, e.g., Tommy Thompson Park, Hamilton Harbor, and Chantry Island (D. V. Weseloh, unpublished data).

\section{Habitat loss and disturbance}

Since the first census, land-use and hydrologic changes have occurred across the Great Lakes basin, potentially influencing the distribution of waterbird colonies (Smith et al. 1991, Herdendorf 1992, Frieswyk and Zedler 2007). Small-scale changes in waterbird colonies can be linked to the direct alteration of supporting habitat. For example, anthropogenic development of the Collingwood Mainland heron colony site rendered this site no longer available to herons. Loss of the heron colony on Ironsides Island also paralleled the loss of nesting habitat (Maxwell et al. 2000; but see below). In 1991, 1001 heron nests were recorded at this site. As the trees that supported these nests slowly died, nests on this island decreased $21 \%$ to 793 in 1999 . By the census in 2008, no herons were recorded nesting at this location.

Changes in water quality and precipitation patterns can also affect nesting populations (Keddy and Reznicek 1982, Morrice et al. 2008). Access to food supply can limit the size, distribution, and productivity of heron colonies (Gibbs 1991, Custer et al. 2004, Tourenq et al. 2004, Witt 2006). Declines in the three focal species, as assessed during the 1999 census, may reflect below-average water levels, a trend that continues within the Great Lakes region (Gronewold and Stow 2014). However, given the similarity in resource use among the three species and the fact that all three exhibited different population trends throughout the 30-year census, hydrological variation is not a likely explanation for these longer term population changes.

Along with nesting habitat change and loss, disturbance can influence feeding and nesting behavior of some waterbird species (Tremblay and Ellison 1979, Rodgers and Smith 1995, Carney and Syndeman 1999). Frequent disturbance near colonies can result in reduced reproductive success and colony abandonment (Hockin et al. 1992). For example, nest predators such as raccoons were reported at Ironsides Island when heron nests declined at that site (L. Harper, personal communication). Human or natural disturbance can also influence competitive and/or predatory interactions among some colonial-nesting species, which can facilitate changes in reproductive success within affected colonies (Skagen et al. 2001).

Interspecific competition for suitable nest sites can influence the reproductive success of colony-nesting waterbird species (reviewed by Burger 1981). Populations of cormorants have increased throughout much of the Great Lakes region (Weseloh et al. 2002, Wires and Cuthbert 2006), and aggressive interactions with cormorants have fostered the assumption that cormorants may directly influence the breeding success of co-occurring species (Skagen et al. 2001, Cuthbert et al. 2002). On a local scale, the abrupt disappearance of night-herons from several colonies in Lake Ontario (Tommy Thompson Park, Peninsulas A and B; Gull, Scotch Bonnet, False Duck, Pigeon, West Brothers, and Snake islands, Appendix 1; and Little Galloo Island, Appendix 
2) correlates with cormorants taking over night-heron nests at these locations (Weseloh et al. 2002; D. V. Weseloh personal observation and unpublished data). As cormorants moved into these locations, night-herons abandoned the colony site if no other suitable habitat was available. If other habitat was available, night-herons moved to the alternate habitat, e.g., Tommy Thompson Park and Hamilton Harbor. Such changes in colony use provide evidence of nonlinear relationships between cormorants and night-herons, interactions that involve interspecific competition and the availability of suitable habitat.

Cuthbert et al. (2002) found that increased cormorant populations alone were not directly tied to changes in waterbird abundance throughout the Great Lakes basin. Changes in heron/ egret nest numbers as reflected herein tend to support Cuthbert et al. (2002). Specifically, the greatest increase in cormorant abundance within the Canadian Great Lakes and adjacent U.S. waters occurred during 1980-1990 (Weseloh et al. 2002), when the abundance of egrets and herons also increased within the Great Lakes basin. Although the abundance of night-herons declined during this same time, the greatest decrease in night-heron abundance occurred between 1991 and 1999, a period of lesser change in the cormorant population.

Cormorants can influence the diversity and structure of vegetation within nest colonies (Hebert et al. 2005, Boutin et al. 2011). Night-herons typically establish nest sites during early stages of plant succession (Hothem et al. 2010), whereas herons and egrets are considered to be less selective (McCrimmon et al. 2011, Vennesland et al. 2011). Successional habitat change, such as that occurring on West Sister Island in Lake Erie, may have reduced the availability of nesting habitat, resulting in population declines and changes in the distribution of night-heron colonies. Prior to the first census, habitats of West Sister Island included open grasslands and shrubs, which were maintained through grazing and other practices (Shieldcastle and Martin 1997, USFWS 2000). By 1991, these shrub habitats, used by nesting night-herons, were replaced by common hackberry (Celtis occidentalis). Concomitant with this habitat change, the number of nesting night-herons declined (Shieldcastle and Martin 1997). Substantial decline in night-heron nests on West Sister Island already occurred by the time cormorants were first recorded nesting on this island in 1992 (Shieldcastle and Martin 1997), suggesting that the presence of nesting cormorants was not a factor contributing to loss of night-herons nesting at this colony.

The abundance of night-heron nests within surveyed river systems, especially the St. Lawrence, Niagara, Detroit, and to a lesser extent St Marys, has increased since the first survey in 1977 (Table 1). Redistribution of this species to these riverine colonies could indicate that with successional habitat change, loss of nest sites, and increases in cormorant numbers at some lake locations, night-herons find increased benefits in nesting at riverine locations. Clearly, more work is needed to fully assess the potential conflicts between cormorants and co-occurring species, especially the three species in this study.

\section{Potential limitations of data}

An important point to note regarding this study is that it is focused on a specific area: habitat on islands and within $1 \mathrm{~km}$ of Great Lakes shoreline. Therefore, the results cannot be extended to the multiple inlands sites where these species nest in the U.S. and Canada Great Lakes region. Inland trends and distribution are not well known for any of the three species and it is possible that declining trends in the Great Lakes may be offset by inland increases and vice versa. Future studies are needed to document trends and distribution at a regional scale.

Vegetation and physical structures can obscure nests, reducing the accuracy of counts. Although nest structures can be distinctive among species, nests can be occupied by species other than those that initially built them, which can lead to misidentification of nests to occupying species. Night-herons build relatively obscured nests that are neither large nor necessarily easy to see. In some situations, this species may nest on the ground, under fallen logs or in small shrubs (Hothem et al. 2010). In more northerly areas, such as at locations in Lake Huron, this species often nests in eastern white cedar (Thuja occidentalis), where nests can be difficult to locate (D. V Weseloh, personal observation). Subsequently, some nests or entire colonies may have been overlooked. With these limitations considered, we advocate the approach of Morris et al. (2003) in referring to these data as a valid index of the number of breeding pairs of each species, while also stressing they represent a conservative minimum estimate of the size of the actual Great Lakes breeding population.

\section{Management actions}

To date, few management actions have been directed at populations of the three heron species in this study. Monitoring the entire Great Lakes population every 10 years allows us to track numbers and trends, and is an important lakes-wide action. Little action is needed for herons and egrets because they are considered not at risk (Wires et al. 2010). Night-herons, however, are a species of special concern in some areas of the Great Lakes (Wires et al. 2010), yet have mostly received only local attention. This local attention has included (1) dedicated vegetative plants on specific islands for night-herons (Quinn et al. 1996, Somers et al. 2007); (2) removal of trees to promote early successional growth favoring night-heron nesting (Shieldcastle and Martin 1997); (3) removal of cormorant nests from previous night-heron nesting areas in hopes of enticing the latter back to nest (D. Tyerman, personal communication); and (4) egg oiling and lethal control of cormorants to entice night-herons back to former nesting sites (T. Dobby unpublished data, I. Mazzocchi unpublished data). However, in many other areas nothing is being done. On six islands in northeastern Lake Ontario near Kingston, Ontario, where night-herons nested between 1977 and 2008 and subsequently abandoned their islands when cormorants started nesting on them, nothing has been done to promote their return to these traditional nesting islands. At many islands in the Great Lakes, "managing for night-herons" is the rationale used to justify lethal control of cormorants; time and continued population monitoring will tell if such actions have benefited the nightherons. Because the question of possible impacts of cormorants on nesting night-herons has not been fully resolved, we recommend an adaptive management type study to examine the cormorant-night-heron relationship at small nesting areas/ islands with no or limited alternative habitat versus large nesting areas with much alternative night-heron habitat. Stronger efforts to prevent/reduce human disturbance at night-heron colonies during the nesting season should also be made. 


\section{CONCLUSION}

Within the Great Lakes region, the night-heron is considered a species of moderate conservation concern, whereas egret and heron are considered species not at risk (Wires et al. 2010). At the regional scale, no evidence through the third decadal census indicated that cormorants were negatively affecting heron populations within the Great Lakes (Cuthbert et al. 2002); however, this conclusion remains contested. Cormorants can greatly affect forest cover (Hebert et al. 2005, 2014), which may negatively impact other nesting waterbirds. For night-herons, shifts in habitat away from early-successional stages can constrain the availability of quality nesting habitat. Alternatively, forest canopy openings created through the activity of nesting cormorants (Boutin et al. 2011) can help set back successional habitats, providing additional nesting opportunities for nightherons in some colonies. Management activities focused on maintaining or restoring early successional habitat within historical confines could benefit night-herons (Shieldcastle and Martin 1997, USFWS 2000).

Increased abundance of night-heron and egret nests within northern river and lake systems provides evidence of a recent northward expansion of their breeding range within the Great Lakes Basin. Such northward expansion could portend changes in distribution coinciding with changing climate (Mortsch et al. 2006). Understanding how climate change will influence heron and egret populations in the Great Lakes region will be best studied through continued monitoring. Planned management activities should continue to endorse collaboration at state, provincial, and federal levels.

Responses to this article can be read online at: http://www.ace-eco.org/issues/responses.php/742

\section{Acknowledgments:}

We wish to thank the Canadian Wildlife Service (CWS; Environment Canada) and the U.S. Fish and Wildlife Service for providing the funding to carry out this work. CWS Enforcement and the Canada Centre for Inland Waters provided significant logistical support for the Canadian censuses. For assistance with the Canadian censuses, we would like to thank the Ontario Ministry of Natural Resources, Parks Canada, Toronto Region Conservation Authority, Long Point Bird Observatory/Bird Studies Canada, McMaster University, Brock University, and Lakehead University. For assistance in U.S. waters, we are indebted to many cooperators and institutions, including Apostle Islands National Lakeshore, Bay Mills Indian Community, Boy Scouts of America, Central Michigan University, Detroit Zoo, Horicon National Wildlife Refuge, Indiana Division of Wildlife, Michigan Department of Natural Resources, Michigan Nature Association, Minnesota Department of Natural Resources, New York State Department of Environmental Conservation, Ohio Division of Wildlife, Richter Museum of Natural History, St. Lawrence Bird Observatory, Shiawasssee National Wildlife Refuge, Sleeping Bear Dunes National Lakeshore, USDA Wildlife Services, William Scharf, and the Wisconsin Department of Natural Resources. We also thank the University of Michigan Biological Station for logistical support and Steve Lewis for unwavering interest in this effort. Charles Smith and J. L. David Smith provided exceptional boat operation expertise and float plane pilot Don DeRuiter, Northwoods Aviation, contributed unprecedented knowledge of Great Lakes islands and waterbird colonies.

\section{LITERATURE CITED}

Blokpoel, H. 1977. Gulls and terns nesting in northern Lake Ontario and the upper St. Lawrence River. Canadian Wildlife Service Progress Notes 75. Canadian Wildlife Service, Ottawa, Ontario, Canada.

Blokpoel, H., J. P. Ryder, I. Seddon, and W. R. Carswell. 1980. Colonial waterbirds nesting in Canadian Lake Superior in 1978. Canadian Wildlife Service Progress Notes 118. Canadian Wildlife Service, Ottawa, Ontario, Canada.

Blokpoel, H., and G. D. Tessier. 1998. Atlas of colonial waterbirds nesting on the Canadian Great Lakes, 1989-1991. Part 5. Herons and egrets in 1991. Canadian Wildlife Service Technical Report Series No. 272. Canadian Wildlife Service, Ottawa, Ontario, Canada.

Boutin, C., T. Dobbie, D. Carpenter, and C. E. Hebert. 2011. Effects of Double-crested Cormorants (Phalacrocorax auritus Less.) on island vegetation, seedbank, and soil chemistry: evaluating island restoration potential. Restoration Ecology 19:720-727. http://dx.doi.org/10.1111/j.1526-100X.2010.00769. $\mathrm{x}$

Buckley, P. A., and F. G. Buckley. 1980. What constitutes a waterbird colony? Reflections from the northeastern United States. Proceedings of the Colonial Waterbird Group 3:1-15.

Burger, J. 1981. A model for the evolution of mixed-species colonies of Ciconiiformes. Quarterly Review of Biology 56:143-167. http://dx.doi.org/10.1086/412176

Cadman, M. D., D. A. Sutherland, G. C. Beck, D. Lepage, and A. R. Couturier, editors. 2007. Atlas of the breeding birds of Ontario 2001-2005. Bird Studies Canada, Environment Canada, Ontario Field Ornithologists, Ontario Ministry of Natural Resources, and Ontario Nature, Toronto, Ontario, Canada.

Carney, K. M., and W. J. Syndeman. 1999. A review of human disturbance effects on nesting colonial waterbirds. Waterbirds 22:68-79. http://dx.doi.org/10.2307/1521995

Custer, C. M., S. A. Suárez, and D. A. Olsen. 2004. Feeding habitat characteristics of the Great Blue Heron and Great Egret nesting along the upper Mississippi River, 1995-1998. Waterbirds 27:454-468. http://dx.doi.org/10.1675/1524-4695(2004)027[0454: FHCOTG]2.0.CO;2

Cuthbert, F. J., and L. Wires. 2013. The fourth decadal U.S. Great Lakes colonial waterbird survey (2007-2010): results and recommendations to improve the scientific basis for conservation and management. Final report. U.S. Fish and Wildlife Service, Fort Snelling, Minnesota, USA.

Cuthbert, F. J., L. R. Wires, and J. E. McKearnan. 2002. Potential impacts of nesting Double-crested Cormorants on Great Blue Herons and Black-crowned Night-herons in the U.S. Great Lakes Region. Journal of Great Lakes Research 28:145-154. http://dx. doi.org/10.1016/S0380-1330(02)70572-8 
Dorr, B. S., J. J. Hatch, and D. V. Weseloh. 2014. Double-crested Cormorant (Phalacrocorax auritus). In A. Poole, editor. The birds of North America online. Cornell Lab of Ornithology, Ithaca, New York, USA.

Ewins, P. J., D. V. Weseloh, and H. Blokpoel. 1995. Within-season variation in nest numbers of Double-crested Cormorants (Phalacrocorax auritus) on the Great Lakes: implications for censusing. Colonial Waterbirds 18:179-192. http://dx.doi. org/10.2307/1521479

Frieswyk, C. B., and J. B. Zedler. 2007. Vegetation change in Great Lakes coastal wetlands: deviation from the historic cycle. Journal of Great Lakes Research 33:366-380. http://dx.doi.org/10.3394/0380-1330 (2007)33[366:VCIGLC]2.0.CO;2

Fuller K., H. Shear, and J. Wittig. 2002. The Great Lakes: an environmental atlas and resource book. Government of Canada and the United States Environmental Protection Agency (EPA) . EPA/The Government of Canada, Toronto, Ontario, Canada.

Gibbs, J. P. 1991. Spatial relationships between nesting colonies and foraging areas of Great Blue Herons. Auk 108:764-770.

Gronewold, A .D., and C. A. Stow. 2014. Water loss from the Great Lakes. Science 343:1084-1085. http://dx.doi.org/10.1126/ science. 1249978

Hebert, C. E., J. Duffe, D. V. C. Weseloh, E. M. T. Senese, and G. D. Haffner. 2005. Unique island habitats may be threatened by Double-crested Cormorants. Journal of Wildlife Management 69:68-76. http://dx.doi.org/10.2193/0022-541X(2005)069<0068: UIHMBT $>2.0 . \mathrm{CO} ; 2$

Hebert, C. E., J. Pasher, D. V. C. Weseloh, T. Dobbie, S. Dobbyn, D. Moore, V. Minelga, and J. Duffe. 2014. Nesting cormorants and temporal changes in island habitat. Journal of Wildlife Management 78:307-313 http://dx.doi.org/10.1002/jwmg.659

Herdendorf, C. E. 1992. Lake Erie coastal wetlands: an overview. Journal of Great Lakes Research 18:533-561. http://dx.doi. org/10.1016/S0380-1330(92)71321-5

Hockin, D., M. Ounsted, M. Gorman, D. Hill, V. Keller, and M. A. Barker. 1992. Examination of the effects of disturbance on birds with reference its importance in ecological assessments. Journal of Environmental Management 36:253-286. http://dx.doi. org/10.1016/S0301-4797(08)80002-3

Hothem, R. L., B. E. Brussee, and W. E. Davis, Jr. 2010. Blackcrowned Night-heron (Nycticorax nycticorax). In A. Poole, editor. The birds of North America online. Cornell Lab of Ornithology, Ithaca, New York, USA.

Keddy, P. A., and A. A. Reznicek. 1982. The role of seed banks in the persistence of Ontario's coastal plain flora. American Journal of Botany 69:13-22. http://dx.doi.org/10.2307/2442827

Kushlan, J. A. 1986. Colonies, sites and surveys: the terminology of colonial waterbird studies. Colonial Waterbirds 9:119-120. http://dx.doi.org/10.2307/1521154

Lemmon, C. R., G. Bugbee, and G. R. Stephens. 1994. Tree damage by nesting Double-crested Cormorants in Connecticut. Connecticut Warbler 14:27-30.
Maxwell, G. R., G. A. Smith, L. Harper, and K. Karwowski. 2000. Great Blue Heron nesting population on Ironsides Island in the St. Lawrence River 1964-1998. Kingbird 50:237-248.

McCrimmon, D. A., Jr., J. C. Ogden, and G. T. Bancroft. 2011. Great Egret (Ardea alba). In A. Poole, editor. The birds of North America online. Cornell Lab of Ornithology, Ithaca, New York, USA.

Morrice, J. A., N. P. Danz, R. R. Regal, J. R. Kelly, G. J. Niemi, E. D. Reavie, T. Hollenhorst, R. P. Axler, A. S. Trebitz, A. M. Cotter, and G. S. Peterson. 2008. Human influences on water quality in Great Lakes coastal wetlands. Environmental Management 41:347-357. http://dx.doi.org/10.1007/s00267-007-9055-5

Morris, R. D., D. V. Weseloh, F. J. Cuthbert, C. Pekarik, L. R. Wires, and L. Harper. 2010. Distribution and abundance of nesting Common and Caspian terns on the North American Great Lakes, 1976 to 1999. Journal of Great Lakes Research 36:44-56. http://dx.doi.org/10.1016/j.jglr.2009.09.008

Morris, R. D., D. V. Weseloh, and J. L. Shutt. 2003. Distribution and abundance of nesting pairs of Herring Gulls (Larus argentatus) on the North American Great Lakes, 1976 to 2000. Journal of Great Lakes Research 29:400-426. http://dx.doi. org/10.1016/S0380-1330(03)70447-X

Morris, R. D., D. V. Weseloh, L. R. Wires, C. Pekarik, F. J. Cuthbert, and D. J. Moore. 2011. Population trends of Ring-billed Gulls breeding on the North American Great Lakes, 1976 to 2009. Waterbirds 34:202-212. http://dx.doi.org/10.1675/063.034.0209

Mortsch, L., J. Ingram, A. Hebb, and S. Doka, editors. 2006. Great Lakes coastal wetland communities: vulnerability to climate change and response to adaptation strategies. Final report submitted to the Canadian Climate Change Action Fund, Natural Resources Canada. Environment Canada and the Department of Fisheries and Oceans, Toronto, Ontario, Canada.

Pekarik, C., C. Hodder, D. V. C. Weseloh, C. Matkovich, L. Shutt, T. Erdman, and S. Matteson. 2009. First nesting of American White Pelican on Lake Superior, Ontario, Canada - status of the American White Pelican in the Great Lakes Region. Ontario Birds 27:42-49.

Quinn, J. S., R. D. Morris, H. Blokpoel, D. V. Weseloh, and P. J. Ewins. 1996. Design and management of bird nesting habitat: tactics for conserving colonial waterbird biodiversity on artificial islands in Hamilton Harbour, Ontario. Canadian Journal of Fisheries and Aquatic Sciences 53(Suppl 1):45-57. http://dx.doi. org/10.1139/f95-260

R Development Core Team. 2012. R: a language and environment for statistical computing. R Project for Statistical Computing, Vienna, Austria.

Rodgers, J. A., Jr., and H. T. Smith. 1995. Set-back distances to protect nesting bird colonies from human disturbance in Florida. Conservation Biology 9:89-99. http://dx.doi.org/10.1046/ j.1523-1739.1995.09010089.x

Scharf, W. C., M. L. Chamberlin, T. C. Erdman, and G. Shugart. 1979. Nesting and migration areas of birds of the U.S. Great Lakes. FWS/OBS-77/22. U.S. Fish and Wildlife Service, Morgantown, West Virginia, USA. 
Scharf, W. C., and G. W. Shugart. 1998. Distribution and abundance of tree-nesting heron and marsh-nesting tern colonies of the U.S. Great Lakes, 1991. W. W. Bowerman and A. S. Roe, editors. Publication No. 2. Gale Gleason Environmental Institute, Lake Superior State University Press, Sault Ste. Marie, Michigan, USA.

Shieldcastle, M. C., and L. Martin. 1997. Colonial waterbird nesting on West Sister Island National Wildlife Refuge and the arrival of Double-crested Cormorants. Pages 115-119 in M. E. Tobin, editor. Symposium on Double-crested Cormorants: population status and management issues in the Midwest (Dec. 9, 1997, Milwaukee, WI). USDA APHIS Technical Bulletin No. 1879. U.S. Department of Agriculture, Animal and Plant Health Inspection Service, Washington, D.C., USA.

Skagen, S. K., C. P. Melcher, and E. Muths. 2001. The interplay of habitat change, human disturbance and species interactions in a waterbird colony. American Midland Naturalist 145:18-28. http://dx.doi.org/10.1674/0003-0031(2001)145[0018:TIOHCH]2.0. $\mathrm{CO} ; 2$

Smith, P. G. R., V. Glooschenko, and D. A. Hagen. 1991. Coastal wetlands of the three Canadian Great Lakes: inventory, current conservation initiatives, and patterns of variation. Canadian Journal of Fisheries and Aquatic Sciences 48:1581-1594. http://dx. doi.org/10.1139/f91-187

Somers, C. M., M. N. Lozer, and J. S. Quinn. 2007. Interactions between Double-crested Cormorants and Herring Gulls at a shared breeding site. Waterbirds 30:241-250. http://dx.doi. org/10.1675/1524-4695(2007)30[241:IBDCAH]2.0.CO;2

Tourenq, C., S. Benhamou, N. Sadoul, A. Sandoz, F. Mesléard, J.-L. Martin, and H. Hafner. 2004. Spatial relationships between tree-nesting heron colonies and rice fields in the Camargue, France. Auk 121:192-202. http://dx.doi.org/10.1642/0004-8038 (2004)121[0192:SRBTHC]2.0.CO;2

Tremblay, J., and L. N. Ellison. 1979. Effects of human disturbance on breeding Black-crowned Night-herons. Auk 96:364-369.

U.S. Fish and Wildlife Service (USFWS). 2000. Ottawa National Wildlife Refuge complex comprehensive conservation plan. Ottawa National Wildlife Refuge, Oak Harbor, Ohio, USA. http://www. fws.gov/Midwest/planning/Ottawa/index.html

Vennesland, R. G., and R. W. Butler. 2011. Great Blue Heron (Ardea herodias). In A. Poole, editor. The birds of North America online. Cornell Lab of Ornithology, Ithaca, New York, USA.

Weseloh, D. V., P. Mineau, S. M. Teeple, H. Blokpoel, and B. Ratcliff. 1986. Colonial waterbirds nesting in Canadian Lake Huron in 1980. Canadian Wildlife Service Progress Note 165. Canadian Wildlife Service, Ottawa, Ontario, Canada.
Weseloh, D. V., S. M. Temple, and H. Blokpoel. 1988. The distribution and status of colonial waterbirds nesting in western Lake Erie. Pages 134-144 in J. F. Downhower, editor. The biogeography of the island region of western Lake Erie. Ohio State University Press, Columbus, Ohio, USA.

Weseloh, D. V. C., C. Pekarik, T. Havelka, G. Barrett, and J. Reid. 2002. Population trends and colony locations of Double-crested Cormorants in the Canadian Great Lakes and immediately adjacent areas, 1990-2000: a manager's guide. Journal of Great Lakes Research 28:125-144. http://dx.doi.org/10.1016/S0380-1330 (02)70571-6

Wires, L. R., and F. J. Cuthbert. 2006. Historic populations of the Double-crested Cormorant (Phalacrocorax auritus): implications for conservation and management in the $21 \mathrm{st}$ century. Waterbirds 29:9-37. http://dx.doi.org/10.1675/1524-4695 (2006)29[9:HPOTDC]2.0.CO;2

Wires, L. R., S. J. Lewis, G. J. Soulliere, S. W. Matteson, D. V. Weseloh, R. P. Russell, and F. J. Cuthbert. 2010. Upper Mississippi Valley/Great Lakes Waterbird Conservation Plan. A plan associated with the Waterbird Conservation for the Americas Initiative. Final report submitted to the U. S. Fish and Wildlife Service. U.S. Fish and Wildlife Service, Fort Snelling, Minnesota, USA.

Witt, J. W. 2006. Great Blue Heron productivity at Mason Neck National Wildlife Refuge in northern Virginia, and the potential impacts of weather during a 13-year interval. Waterbirds 29:345-349. http://dx.doi.org/10.1675/1524-4695(2006)29[345:GBHPAM] 2.0. $\mathrm{CO} ; 2$ 
Appendix 1. Canadian Black-crowned Night-heron colony sites and number of nests per location in Canadian waters during each of four censuses. Water body codes, presented in order reflecting an east- west gradient, are: SLR (St. Lawrence River), LO (Lake Ontario), NR (Niagara River), LE (Lake Erie), DR (Detroit River), LSC (Lake St. Clair) and LH (Lake Huron). Blank entries indicate no nests reported at colony site.

\begin{tabular}{|c|c|c|c|c|c|c|c|}
\hline $\begin{array}{l}\text { Water } \\
\text { body }\end{array}$ & Site Name & Lat. & Long. & 1977 & 1991 & 1999 & 2008 \\
\hline$\overline{\mathrm{SLR}}$ & McNair Is. & 44.59 & -75.66 & & & 46 & 7 \\
\hline SLR & Bergin Is. & 45.02 & -74.86 & & & & 59 \\
\hline SLR & Strachan Is. & 45.02 & -74.81 & & & & 5 \\
\hline SLR & W of Strachan Is. & 45.02 & -74.81 & & & & 6 \\
\hline SLR & $\mathrm{S}$ of $31 \mathrm{G} 006$ & 45.02 & -74.81 & & & & 62 \\
\hline SLR & E of Strachan Is. & 45.02 & -74.81 & & & & 1 \\
\hline SLR & Dickerson Is. & 45.02 & -74.8 & & & & 1 \\
\hline SLR & Dodens Is. & 45.04 & -74.57 & & & & 1 \\
\hline LO & Windermere Basin & 43.26 & -79.78 & & & & 119 \\
\hline LO & Hamilton Hrbr, Eastport & 43.28 & -79.79 & 5 & 60 & 96 & 17 \\
\hline LO & Hamilton Hrbr, North Is. & 43.31 & -79.8 & & & 37 & 8 \\
\hline LO & Hamilton Hrbr, Centre Is. & 43.31 & -79.8 & & & & 5 \\
\hline LO & Hamilton Hrbr, South Is. & 43.3 & -79.8 & & & & 12 \\
\hline LO & Hamilton Hrbr, Farre Is. & 43.31 & -79.81 & & 14 & & \\
\hline LO & Toronto Hrbr, Mugg's Is. & 43.63 & -79.38 & 56 & & & \\
\hline LO & Tommy Thomson Pk, Pen. A & 43.62 & -79.34 & & 14 & & \\
\hline LO & Tommy Thomson Pk, Pen. B & 43.62 & -79.34 & & 111 & & 87 \\
\hline LO & Tommy Thomson Pk, Pen. C & 43.63 & -79.34 & & 667 & 1265 & 480 \\
\hline LO & High Bluff Is. & 43.97 & -77.75 & 79 & 37 & 38 & 80 \\
\hline LO & Gull Is. & 43.98 & -77.74 & 27 & & 21 & \\
\hline LO & Scotch Bonnet Is. & 43.9 & -77.54 & & 27 & & \\
\hline LO & False Duck Is. & 43.95 & -76.8 & & 48 & & \\
\hline LO & Pigeon Is. & 44.07 & -76.55 & 65 & & & \\
\hline LO & West island of the Brother Iss. & 44.21 & -76.64 & & & 9 & \\
\hline LO & Middle island of the Brother Iss. & 44.21 & -76.63 & & & & 19 \\
\hline LO & East island of the Brother Iss. & 44.2 & -76.62 & & & & 12 \\
\hline LO & Snake Is. & 44.19 & -76.54 & & 16 & & \\
\hline LO & Little Cataraqui River Marsh & 44.26 & -76.52 & & 2 & & \\
\hline NR & Unnamed Is. \#1 & 43.07 & -79.07 & 65 & 200 & 202 & 296 \\
\hline NR & Is. between Unnamed Is. \#1 and Unnamed Is. \#2 & 43.07 & -79.08 & & & & 30 \\
\hline NR & Unnamed Is. \#3 & 43.07 & -79.08 & & 213 & & \\
\hline NR & Unnamed Is. \#2 & 43.07 & -79.08 & & 13 & 44 & 52 \\
\hline LE & Port Colborne & 42.87 & -79.26 & & & 5 & 10 \\
\hline LE & Middle Sister Is. & 41.85 & -82.86 & & & 15 & 12 \\
\hline LE & East Sister Is. & 41.81 & -82.86 & 350 & 106 & 9 & 16 \\
\hline LE & Middle Is. & 41.68 & -82.68 & & 45 & 69 & 27 \\
\hline LE & Pelee Is. & 41.83 & -82.64 & 870 & & & \\
\hline DR & Turkey Is. & 42.19 & -82.11 & & & & 57 \\
\hline LSC & Squirrel Is. & 42.54 & -82.56 & & 10 & & \\
\hline LSC & Bassett Is. & 42.5 & -82.59 & & 88 & & \\
\hline LH & Mad Reef & 44.96 & -81.42 & & & 48 & 44 \\
\hline LH & E-central Chimney Reefs & 44.84 & -81.35 & & & & 4 \\
\hline LH & Shoal off S tip of 41A008 & 44.84 & -81.35 & & & 1 & \\
\hline LH & W-central Chimney Reefs & 44.84 & -81.36 & & & & 15 \\
\hline LH & SW Chimney Reefs & 44.84 & -81.36 & & & 12 & 14 \\
\hline LH & $0.5 \mathrm{~km} \mathrm{SE}$ of Beament Is. & 44.79 & -81.34 & & & & 3 \\
\hline LH & Warren Is. & 44.79 & -81.34 & 56 & 29 & 64 & 61 \\
\hline LH & NE of Warren Is. & 44.79 & -81.34 & & & 5 & \\
\hline LH & $\mathrm{N}$ of Argyle Iss.. & 44.78 & -81.33 & & 9 & 8 & \\
\hline LH & $\mathrm{W}$ island of Argyle Iss. & 44.78 & -81.33 & & & 18 & \\
\hline LH & SW of Argyle Iss. & 44.78 & -81.33 & & & & 5 \\
\hline LH & SSW of Argyle Iss. & 44.77 & -81.33 & & & & 6 \\
\hline LH & Basswood Is. & 44.76 & -81.32 & & & & 1 \\
\hline LH & Barrier Is. & 44.98 & -81.08 & & & & 2 \\
\hline LH & Gray Is. & 44.98 & -80.02 & & & 50 & \\
\hline LH & SE of Gray Is. & 44.98 & -80.02 & & 3 & & \\
\hline LH & Gull Is. & 44.71 & -80.04 & & & & 2 \\
\hline LH & Nottawasaga Is. & 44.54 & -80.26 & 172 & 107 & 117 & 235 \\
\hline LH & Chantry Is. & 44.49 & -81.4 & 97 & 100 & 50 & 39 \\
\hline LH & Red Bay & 44.8 & -81.28 & & 14 & & \\
\hline LH & Batture Is. & 45.97 & -83.07 & & & 4 & 4 \\
\hline LH & Thibault Is. & 45.77 & -82.93 & & & & 13 \\
\hline LH & $\mathrm{W}$ of Walker Point & 45.55 & -82.08 & 1 & & & \\
\hline LH & East Mound & 45.85 & -81.63 & & & & 40 \\
\hline LH & Papoose Is. & 45.86 & -81.36 & & & & 6 \\
\hline LH & James Is. & 45.44 & -81.74 & 2 & & 42 & \\
\hline LH & Snake Is. and NW shoal & 45.34 & -81.63 & 1 & & 3 & 2 \\
\hline LH & Halfmoon Is. & 45.44 & -81.47 & & & 3 & \\
\hline LH & N South Limestone Is. & 45.39 & -80.53 & & & & 59 \\
\hline LH & S South Limestone Is. & 45.39 & -80.53 & & & & 4 \\
\hline LH & S of Limestone Is & 45.38 & -80.53 & & & 5 & \\
\hline LH & Loxton Is. & 45.22 & -80.23 & & & 2 & \\
\hline LH & Rigby and islet to SE & 45.21 & -80.21 & & & 18 & 13 \\
\hline LH & W of Northwest Pine Is. & 45.02 & -80.06 & & & & 15 \\
\hline LH & Gilead Rock & 45.01 & -80.04 & & & 2 & 33 \\
\hline LH & Long Is. & 45.09 & -80.31 & & & & 37 \\
\hline LH & Carpmeal Is. & 46.07 & -81.9 & & & & 15 \\
\hline LH & Perrique Is. & 46.14 & -83.76 & & & & 2 \\
\hline LH & Gull Is. & 46.16 & -83.62 & & & & 1 \\
\hline LH & Anchor Is. & 46.14 & -83.34 & & & & 1 \\
\hline LH & Bird Is. & 46.14 & -83.34 & & & & 8 \\
\hline LH & Middle Grant Is. & 46.14 & -83.32 & & & 2 & 6 \\
\hline LH & N rock Howland Rocks & 46.05 & -82.43 & & & 1 & \\
\hline \multirow[t]{2}{*}{ LH } & S rock Howland Rocks & 46.05 & -82.43 & & & 2 & 12 \\
\hline & \multicolumn{3}{|c|}{ Census total, \# of colonies censused } & $\begin{array}{c}1846,14 \\
(132,232)\end{array}$ & $\begin{array}{l}1933,23 \\
(84,140)\end{array}$ & $\begin{array}{l}2313,34 \\
(68,216)\end{array}$ & $\begin{array}{l}2183,57 \\
(38,79)\end{array}$ \\
\hline
\end{tabular}


Appendix 2. U.S. Black-crowned Night-heron colony sites and number of nests per location in U.S. waters during each of four censuses. Water body codes, presented in order reflecting an east - west gradient, are: LO (Lake Ontario), NR (Niagara River), LE (Lake Erie), DR (Detroit River), LH (Lake Huron), LM (Lake Michigan), SMR (St. Marys River) and LS (Lake Superior). Blank entries indicate no nests reported at colony site.

\begin{tabular}{|c|c|c|c|c|c|c|c|}
\hline $\begin{array}{l}\text { Water } \\
\text { body }\end{array}$ & Site Name & Lat. & Long. & 1977 & 1991 & 1999 & 2008 \\
\hline LO & Little Galloo Is. & 43.53 & -76.24 & 130 & 12 & 1 & \\
\hline LO & Gull Is. & 43.55 & -76.11 & & & 41 & 78 \\
\hline LO & Bass Is. & 43.55 & -76.1 & & & 6 & \\
\hline LO & Calf Is. & 43.52 & -76.22 & & & 6 & 16 \\
\hline NR & Motor (Pirate) Is. & 42.57 & -78.56 & & & 38 & 98 \\
\hline LE & West Sister Is. & 41.44 & -83.06 & 3000 & 1240 & 387 & 460 \\
\hline LE & Green Is. & 41.39 & -82.52 & & & & 4 \\
\hline LE & Sandusky turning Point & 41.28 & -82.55 & & 191 & 73 & 53 \\
\hline LE & Pt Mouillee & 41.56 & -83.11 & & 137 & & 250 \\
\hline LH & Saddlebag Is. & 45.57 & -84.02 & & & 5 & 5 \\
\hline LH & Bear Is. & 45.58 & -84.14 & & & & 32 \\
\hline LH & Crow Is. & 45.58 & -84.14 & & & & 1 \\
\hline LH & Goose Is. & 45.55 & -84.25 & 13 & 2 & 25 & \\
\hline LH & Gull Is. & 45.03 & -83.14 & 29 & 31 & 13 & \\
\hline LH & Grassy Is. & 45.02 & -83.26 & 18 & 18 & 9 & \\
\hline LH & Scarecrow Is. & 44.54 & -83.19 & & 5 & & 1 \\
\hline LH & Bird Is. & 44.53 & -83.19 & & 1 & 10 & 22 \\
\hline LH & Little Charity Is. & 44 & -83.28 & 86 & 44 & 19 & \\
\hline LH & Charity Reef & 44.01 & -83.26 & & & & 7 \\
\hline LH & Nayanquing Dike & 43.46 & -83.56 & 64 & & & \\
\hline LH & Channel Is. & 43.41 & -83.49 & 16 & & & \\
\hline LH & Windy Pt Weadock & 43.39 & -83.5 & 4 & & & \\
\hline LH & Saginaw & 43.41 & -83.49 & & 260 & 480 & 210 \\
\hline LH & Pitcher's Reef & 43.46 & -83.29 & & & & 9 \\
\hline LM & Epoufette Is. & 46.03 & -85.12 & & & 8 & \\
\hline LM & Little Hog Is. & 46.04 & -85.17 & & 3 & & 4 \\
\hline LM & Round Is. & 45.44 & -86.45 & 26 & & 48 & 5 \\
\hline LM & St Vitals Is. & 45.48 & -86.45 & 2 & & & 24 \\
\hline LM & Green Is. & 45.03 & -87.3 & 90 & 364 & & \\
\hline LM & Hat Is. & 45.06 & -87.19 & 79 & 3 & & \\
\hline LM & Jack Is. & 45.1 & -87.16 & 20 & 13 & 5 & \\
\hline LM & Little Strawberry Is. & 45.1 & -87.16 & & & & 113 \\
\hline LM & Big Sister Is. & 45.13 & -87.09 & & & 33 & \\
\hline LM & Hog Is. & 45.21 & -86.51 & & & & 2 \\
\hline LM & Pilot Is. & 45.17 & -86.55 & & 9 & 2 & 9 \\
\hline LM & Big Gull Is. & 45.3 & -86.43 & & & 8 & 6 \\
\hline LM & Little Gull Is. & 45.3 & -86.43 & 5 & & 6 & \\
\hline LM & Big Spider Is. & 45.12 & -86.58 & 11 & & & \\
\hline LM & Rocky Is. & 45.36 & -86.42 & & 22 & 68 & \\
\hline LM & Poverty Is. & 45.32 & -86.4 & 8 & & & \\
\hline LM & Marinette Marine Corp & 45.06 & -87.37 & & & & 15 \\
\hline LM & Green Is. Mackinac & 45.5 & -84.45 & 10 & 30 & 61 & 5 \\
\hline LM & St Helena Is. & 45.52 & -84.52 & & & & 27 \\
\hline LM & Gull Is. & 45.42 & -85.5 & & & & 17 \\
\hline LM & Squaw Is. & 45.5 & -85.35 & & & & 7 \\
\hline LM & Hat Is. & 45.49 & -85.18 & & & 3 & 7 \\
\hline LM & Oconto R North Side & 44.53 & -87.5 & 300 & & & \\
\hline LM & Long Tail Point & 44.36 & -87.59 & 15 & & & \\
\hline LM & Willow Is. & 44.34 & -87.59 & 224 & & & \\
\hline LM & Lone Tree Is. & 44.33 & -87.59 & & 270 & 140 & 29 \\
\hline LM & Cat Is. & 44.33 & -88 & 70 & 80 & 33 & 2 \\
\hline LM & Kidney Is. & 44.32 & -88 & & 65 & 56 & 6 \\
\hline LM & Spring Bluff Nature Reserve & 42.29 & -87.48 & & & & 14 \\
\hline LM & Lake Calumet Dikes & 41.4 & -87.35 & & & & 10 \\
\hline LM & Inland Steel & 41.4 & -87.24 & & & 56 & 255 \\
\hline LM & Lincoln Park Zoo & 41.55 & -87.38 & & & & 21 \\
\hline SMR & Squaw Is. & 46.02 & -83.54 & & & & 6 \\
\hline \multirow[t]{2}{*}{ LS } & Round Is. & 46.26 & -84.31 & & & & 3 \\
\hline & \multicolumn{3}{|c|}{ Census total, \# of colonies censused } & $\begin{array}{c}4220,22 \\
(192,632)\end{array}$ & $\begin{array}{c}2800,21 \\
(133,275)\end{array}$ & $\begin{array}{l}1640,28 \\
(59,111)\end{array}$ & $\begin{array}{l}1833,37 \\
(50,96)\end{array}$ \\
\hline
\end{tabular}


Appendix 3. Great Egret colony sites and number of nests per location in Canadian waters during each of four censuses. Water body codes, presented in order reflecting an east - west gradient, are: LO (Lake Ontario), LE (Lake Erie) and LH (Lake Huron). Blank entries indicate no nests reported at colony site.

\begin{tabular}{|c|c|c|c|c|c|c|c|}
\hline \multirow{2}{*}{$\begin{array}{l}\text { Water } \\
\text { body }\end{array}$} & \multirow{2}{*}{$\begin{array}{l}\text { Site name } \\
\text { Tommy Thomson Park, C }\end{array}$} & Lat. & Long. & \multirow[t]{2}{*}{1977} & \multirow[t]{2}{*}{1991} & \multirow[t]{2}{*}{1999} & \multirow{2}{*}{$\frac{2008}{6}$} \\
\hline & & 43.63 & -79.34 & & & & \\
\hline LO & High Bluff Is. & 43.97 & -77.75 & & & 2 & 27 \\
\hline LE & Middle Sister Is. & 41.85 & -82.86 & 3 & & & 34 \\
\hline $\mathrm{LE}$ & East Sister Is. & 41.81 & -82.86 & 10 & 141 & 17 & 12 \\
\hline $\mathrm{LE}$ & Middle Is. & 41.68 & -82.68 & & 2 & 15 & 15 \\
\hline LE & Pelee Is. & 41.83 & -82.64 & 8 & & & \\
\hline LH & Shoal W of Cedar Point & 43.14 & -82.07 & & & & 6 \\
\hline LH & E cent. island Chimney Reefs & 44.84 & -81.35 & & & & 1 \\
\hline LH & Nottawasaga Is. & 44.54 & -80.26 & & 7 & 40 & 141 \\
\hline \multirow[t]{2}{*}{ LH } & Chantry Is. & 44.49 & -81.4 & & 6 & 20 & 69 \\
\hline & $\begin{array}{l}\text { Census total, \# of col } \\
\text { Mean colony size }\end{array}$ & $\begin{array}{l}\text { mies censuse } \\
\text { (mean, } \mathrm{SD})\end{array}$ & & $\begin{array}{l}21,3 \\
(7,4)\end{array}$ & $\begin{array}{c}156,4 \\
(39,68)\end{array}$ & $\begin{array}{c}94,5 \\
(19,14)\end{array}$ & $\begin{array}{c}311,9 \\
(35,45)\end{array}$ \\
\hline
\end{tabular}

Erratum: Appendix 3 in the original publication of this paper contained incorrect data. The correction was made on 17 September 2019. 
Appendix 4. Great Egret colony sites and number of nests per location in U.S. waters during each of four censuses. Water body codes, presented in order reflecting an east - west gradient, are: DR (Detroit River), LE (Lake Erie), LH (Lake Huron), LM (Lake Michigan), LSC (Lake St. Clair), NR (Niagara River). Blank entries indicate no nests reported at colony site.

\begin{tabular}{|c|c|c|c|c|c|c|c|}
\hline Water body & Site name & Lat. & Long. & 1977 & 1991 & 1999 & 2008 \\
\hline NR & Motor Is. & 42.57 & -78.56 & & & 7 & 20 \\
\hline LE & West Sister Is. & 41.44 & -83.06 & 200 & 1040 & 840 & 760 \\
\hline LE & Green Is. & 41.39 & -82.52 & & & & 51 \\
\hline LE & Winous Pt. & 41.28 & -82.58 & & & 7 & \\
\hline LE & Sandusky Turning Point & 41.28 & -82.55 & & 51 & 37 & 132 \\
\hline LE & Pt. Mouillee & 41.56 & -83.11 & & 312 & & \\
\hline LE & Detroit Edison Pond Is. & 41.53 & -83.21 & & 22 & & \\
\hline LE & Ottawa Shooting Club & 41.25 & -83.02 & & & & 5 \\
\hline DR & Stoney Is. & 42.07 & -83.08 & 23 & & & \\
\hline LSC & Dickinson Is. & 42.37 & -82.38 & 1 & & & \\
\hline LH & Grassy Is. & 45.02 & -83.26 & & & & 51 \\
\hline LH & Little Charity Is. & 44 & -83.28 & & 29 & 134 & 18 \\
\hline $\mathrm{LH}$ & Charity Reef & 44.01 & -83.26 & & & & 1 \\
\hline LH & Saginaw & 43.41 & -83.49 & & 33 & 243 & 307 \\
\hline LH & Pitcher's Reef & 43.46 & -83.29 & & & & 66 \\
\hline LM & Round Is. & 45.44 & -86.45 & & & & 11 \\
\hline LM & St Vitals Is. & 45.48 & -86.45 & & & & 4 \\
\hline LM & Marinette Marine Corp & 45.06 & -87.37 & & & & 66 \\
\hline LM & Lone Tree Is. & 44.33 & -87.59 & & & & 44 \\
\hline LM & Cat Is. & 44.33 & -88 & & & 7 & \\
\hline \multirow[t]{2}{*}{ LM } & Inland Steel & 41.4 & -87.24 & & & & 62 \\
\hline & \multicolumn{3}{|c|}{$\begin{array}{r}\text { Census total, \# of colonies censused } \\
\text { Mean colony size }\end{array}$} & $\begin{array}{c}224,3 \\
(75,109)\end{array}$ & $\begin{array}{c}1487,6 \\
(248,404)\end{array}$ & $\begin{array}{c}1275,7 \\
(182,303)\end{array}$ & $\begin{array}{l}1598,15 \\
(107,196)\end{array}$ \\
\hline
\end{tabular}




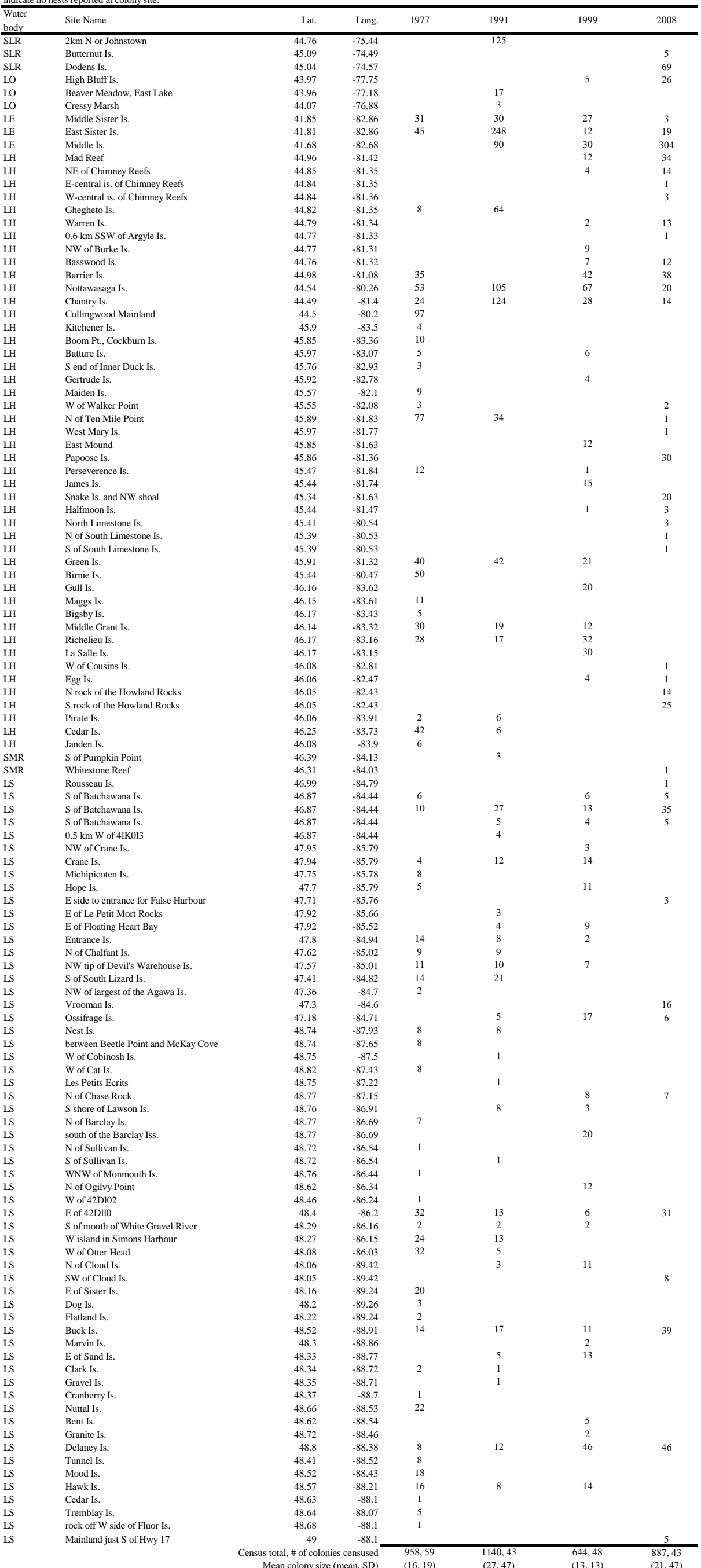


Appendix 6. Great Blue Heron colony sites and number of nests per location in U.S. waters during each of four censuses. Water body codes, presented in order reflecting an east - west gradient, are: SLR (St. Lawrence River), NR (Niagara River), LE (Lake Erie), DR (Detroit River), LSC (Lake St. Clair), LH (Lake Huron), LM (Lake Michigan), SMR (St. Marys River) and LS (Lake Superior). Blank entries indicate no nests reported at colony site.

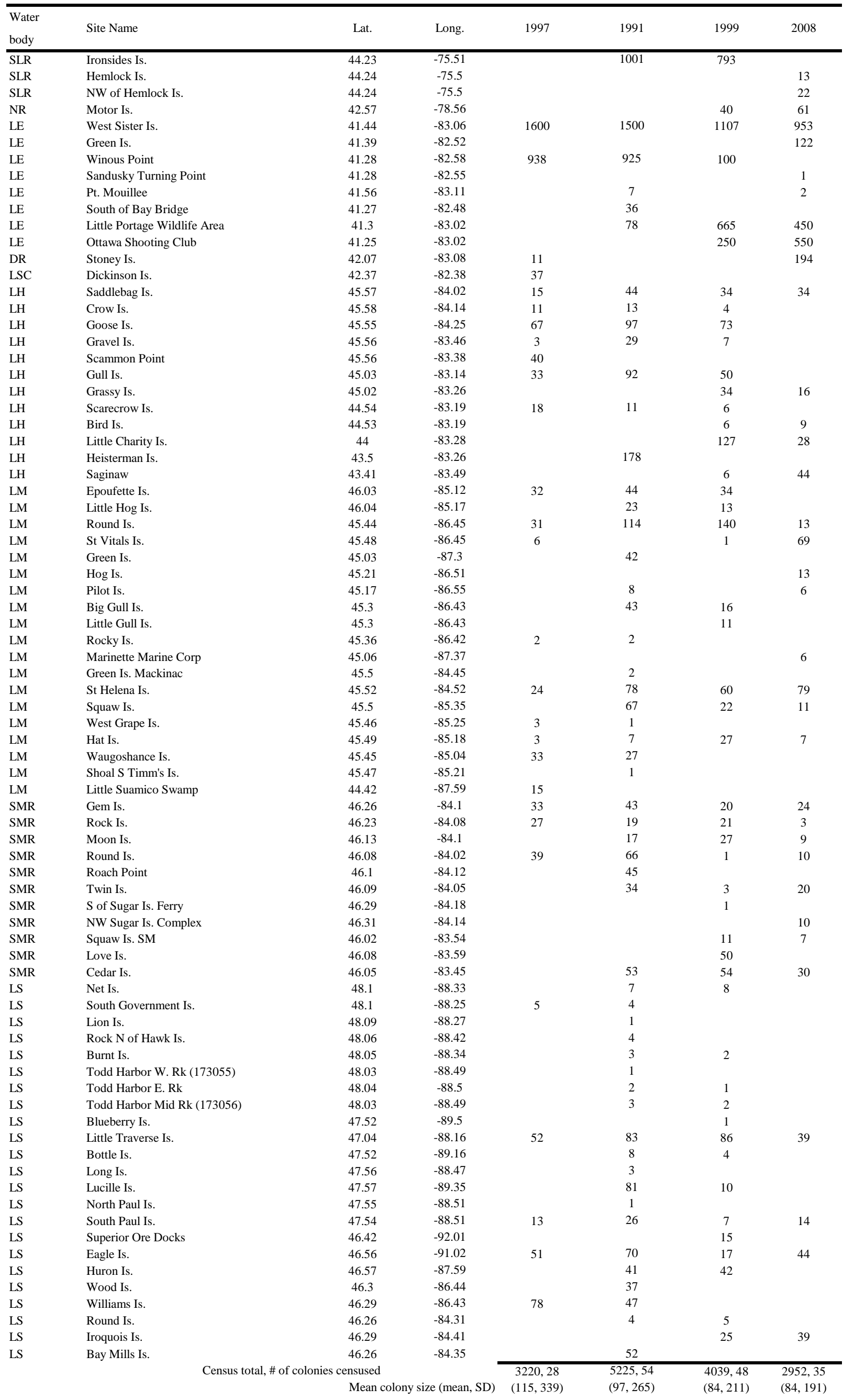

